\title{
STABILIZATION OF CLAY POWDER WITH MINERAL WOOL FLY ASH
}

\author{
Mindaugas ZAKARKA (D, Rimantas MACKEVIČIUS (D, Šarūnas SKUODIS(D)*, \\ Danutė SLIŽYTĖ®D, Andrius KUDŽMA(i) \\ Faculty of Civil Engineering, Vilnius Gediminas Technical University, Vilnius, Lithuania
}

Received 03 January 2020; accepted 29 January 2020

\begin{abstract}
The aim of this article - to determine short term and long term strengthening of clay soil, by strengthening it with fly ash obtained during the production of mineral wool. This article introduces research which is used to determine the optimal ratio of fly ash in cement suspension for strengthening of clay soil. Samples which were investigated in this research work prepared by mixing Portland cement, mineral wool fly ash, clay powder, sand and water. All investigated samples compressive strength after 6 months exceeded 1.7 MPa. It is enough of such strength in geotechnics to conduct strengthening of soil and it is possible to argue that soil is strengthened.
\end{abstract}

Keywords: clay, soil stabilization, fly ash, soil improvement, mineral wool, comprehensive strength.

\section{Introduction}

When the level of economy and consumerism rises, the problem of waste treatment is becoming more and more apparent. In Europe there are approximately 16 tonnes of waste per capita during the year, and approximately 6 tonnes are recycled (European Commission, 2010). One of methods to treat waste is incineration, during which the by-products are obtained - bottom ash and fly ash (FA). The ash is obtained during waste incineration, biofuel burning, mineral wool production, etc. Bottom ash may be used in construction (Zabihi-Samani et al., 2018), especially in the roads (Vaitkus et al., 2017), included into the production process or disposed in mines. FA utilization problem is more complicate, because FA accounts for $15 \%$ of total ash (Pundinaité-Barsteigienè et al., 2017). Not all FA may be used because of poor quality (Giergiczny et al., 2019). Collection, transportation and work with FA is more complicate than with bottom ash because of fine particles (Supancic \& Obernberger, 2011). FA may change the fine particles of other materials and has binding properties (Rutkauskas, 2018).

One of methods to use FA in geotechnics is to change a part of cement into FA and to apply such mix in order to strengthen weak soil (Pentti, 2001), by using jet grouting. During jet grouting, into cement suspension a certain part of cement is being changed into FA. Depending on type and ratio of FA different short term and long term values of strength are obtained (Essler \& Yoshida, 2004; Hemalatha \& Ramaswamy, 2017). It is important, that it is possible to strengthen clay soils with FA high in calcium as well (Kolias et al., 2004). Another possibility is to refuse using cement and use only FA (Cristelo et al., 2013). The results of this test are very advantageous, but the effect which is obtained differs from jet grouting with cement suspension. By using cement suspension, $80-85 \%$ of grouted concrete strength value is reached during 28 days (Sližyte et al., 2010). When a binder is FA, values of strength constantly grow and strengthening does not stop during the one year period (Cristelo et al., 2011; Marinković \& Dragaš, 2018).

Another method to strengthen soils is relevant in road construction, in order to install strong soil layer (Turner, 1997; Zokaité, 2015). Strong soil layer allows to reduce the thickness of the asphalt layer (Parsons \& Kneebone, 2005). It is possible to strengthen soil with FA without cement admixture (Mishra \& Rath, 2011; Supancic \& Obernberger, 2011). This method solves the problem of FA utilisation, but it is possible to apply it only to low intensity roads. Another problem appears due to rising dust during work. Also it is possible to mix the layer of weak soil with cement or with cement and FA. The advantage of this method is that clay soils can be mixed with cement as well.

*Corresponding author. E-mail: sarunas.skuodis@vgtu.lt 
One of the main problems while working with FA is that their composition is very different and it depends on incinerated materials (Vaitkus et al., 2017; Rudžionis \& Ivanauskas, 2004). The properties of FA which were collected even in the same factory but in different times may differ (Rutkauskas, 2018), therefore FA collected during the production of mineral wool gain and advantage due to constant and more predictable composition. During production of mineral wool, bottom ash is returned to production process, it is possible to recycle used wool as well (Väntsi \& Kärki, 2014; Balkevičius et al., 2007). Only FA stay as a by-product, it is not returned to production process due to fine particles.

Usually FA collected in thermoelectric power plant are used in tests, therefore the tests conducted using FA collected in mineral wool production is a new experience. FA from mineral wool production, in comparison with thermoelectric power plant $\mathrm{FA}$, have $5 \%$ less $\mathrm{SiO}_{2}$, $5 \%$ more $\mathrm{Fe}_{2} \mathrm{O}_{3}, 13 \%$ less $\mathrm{CaO}, 9 \%$ more $\mathrm{MgO}, 6 \%$ more $\mathrm{Na}_{2} \mathrm{O}$, etc. (Česnauskas, 2018). Stabilisation of weak clay soils is a relevant problem which needs to be solved. The aim of this article - to determine short term and long term strengthening of clay soil, by strengthening it with fly ash obtained during the production of mineral wool. This article introduces research which is used to determine the optimal ratio of fly ash in cement suspension for strengthening of clay soil.

\section{Testing methodology}

Samples were prepared by mixing Portland cement, FA, clay powder, sand and water. FA used for tests were obtained from mineral wool production process as the waste, the chemical composition of which is presented in Table 1 (Stonys et al., 2016). Samples are produced using Portland concrete CEM I 42,5 R, which corresponds to LST EN 197-1:2013 (Lietuvos standartizacijos departamentas, 2013), clay powder, the chemical composition of which is presented in Table 2. Used sand, the grading curve of which is shown in Figure 1, coefficient of uniformity $\mathrm{C}_{\mathrm{u}}=$ 2.77 ir coefficient of curvature $\mathrm{C}_{\mathrm{c}}=0.90$. Granulometric composition was determined according to specifications of standards LST CEN ISO/TS 17892-4:2017 (Lietuvos standartizacijos departamentas, 2017) and LST CEN ISO/ TS 17892-12:2018 (Lietuvos standartizacijos departamentas, 2018).
To each different composition of mixture three sets of cylindric samples were prepared, the diameter of which $4.5 \mathrm{~cm}$, height $7.0 \mathrm{~cm}$. Overall 15 different compositions were investigated in tests, these compositions are presented in Table 3. At first five ratios of cement and fly ashes were prepared: $100 \% \mathrm{C}$ with $0 \% \mathrm{FA}, 90 \% \mathrm{C}$ with $10 \% \mathrm{FA}$, $80 \%$ C with $20 \% \mathrm{FA}$, and $70 \% \mathrm{C}$ with $30 \% \mathrm{FA}$. Three clay mixtures were mixed as well, which are made of $80 \% \mathrm{CP}$ and $20 \% \mathrm{Sa}, 60 \% \mathrm{CP}$ and $40 \% \mathrm{Sa}$ and $40 \% \mathrm{CP}$ and $60 \%$ Sa. Plastic and liquid limits of clay soils are presented in Figure 2.

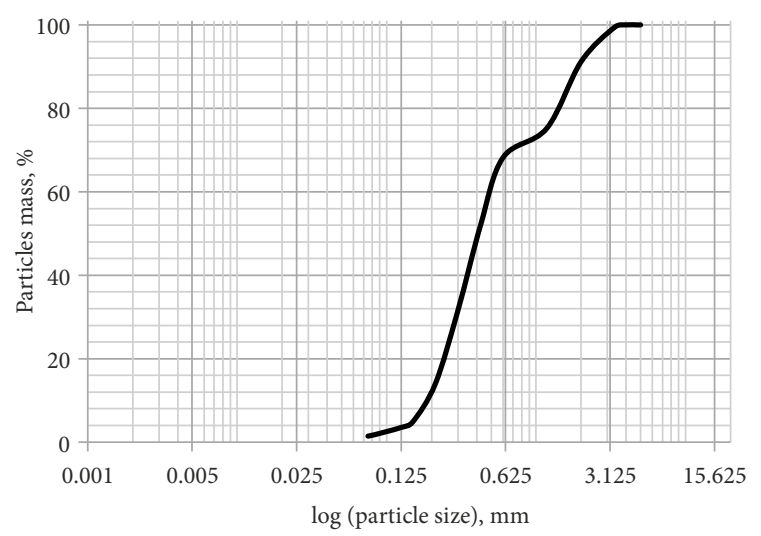

Figure 1. Granulometric composition of investigated sand



Figure 2. Plastic and liquid limits of clay mixtures

Table 1. Chemical composition of fly ash, \%

\begin{tabular}{|c|c|c|c|c|c|c|c|c|c|c|c|}
\hline $\mathrm{SiO}_{2}$ & $\mathrm{Al}_{2} \mathrm{O}_{3}$ & $\mathrm{Fe}_{2} \mathrm{O}_{3}$ & $\mathrm{CaO}$ & $\mathrm{MgO}$ & $\mathrm{Na}_{2} \mathrm{O}$ & $\mathrm{K}_{2} \mathrm{O}$ & $\mathrm{TiO}_{2}$ & $\mathrm{SO}_{3}$ & $\mathrm{Cl}$ & other & LOI \\
\hline 40.6 & 2.14 & 6.91 & 3.52 & 11.1 & 6.71 & 6.34 & 0.23 & 2.41 & 4.58 & 4.67 & 10.79 \\
\hline
\end{tabular}

Table 2. Chemical composition of clay powder, \%

\begin{tabular}{|c|c|c|c|c|c|c|c|c|c|}
\hline $\mathrm{SiO}_{2}$ & $\mathrm{Al}_{2} \mathrm{O}_{3}$ & $\mathrm{TiO}_{2}$ & $\mathrm{Fe}_{2} \mathrm{O}_{3}$ & $\mathrm{MnO}$ & $\mathrm{MgO}$ & $\mathrm{CaO}$ & $\mathrm{Na}_{2} \mathrm{O}$ & $\mathrm{K}_{2} \mathrm{O}$ & $\mathrm{P}_{2} \mathrm{O}_{5}$ \\
\hline $55.0-62.1$ & $15.7-17.7$ & $0.7-0.9$ & $6.1-7.9$ & $0.1-0.2$ & $2.2-3.2$ & $0.3-1.8$ & $0.1-0.3$ & $2.9-3.5$ & $0.1-0.2$ \\
\hline
\end{tabular}


Table 3. Composition of samples

\begin{tabular}{|c|c|c|c|c|c|}
\hline Sample No. & C quantity, \% & FA quantity, \% & $\mathrm{W} /(\mathrm{C}+\mathrm{FA})$ & $\mathrm{CP}$ quantity, \% & Sa quantity, $\%$ \\
\hline 1 & 100 & 0 & 1 & 80 & 20 \\
\hline 2 & 100 & 0 & 1 & 60 & 40 \\
\hline 3 & 100 & 0 & 1 & 40 & 60 \\
\hline 4 & 90 & 10 & 1 & 80 & 20 \\
\hline 5 & 90 & 10 & 1 & 60 & 40 \\
\hline 6 & 90 & 10 & 1 & 40 & 60 \\
\hline 7 & 80 & 20 & 1 & 80 & 20 \\
\hline 8 & 80 & 20 & 1 & 60 & 40 \\
\hline 9 & 80 & 20 & 1 & 40 & 60 \\
\hline 10 & 70 & 30 & 1 & 80 & 20 \\
\hline 11 & 70 & 30 & 1 & 60 & 40 \\
\hline 12 & 70 & 30 & 1 & 40 & 60 \\
\hline 13 & 60 & 40 & 1.5 & 80 & 20 \\
\hline 14 & 60 & 40 & 1.5 & 60 & 40 \\
\hline 15 & 60 & 40 & 1.5 & 40 & 60 \\
\hline
\end{tabular}

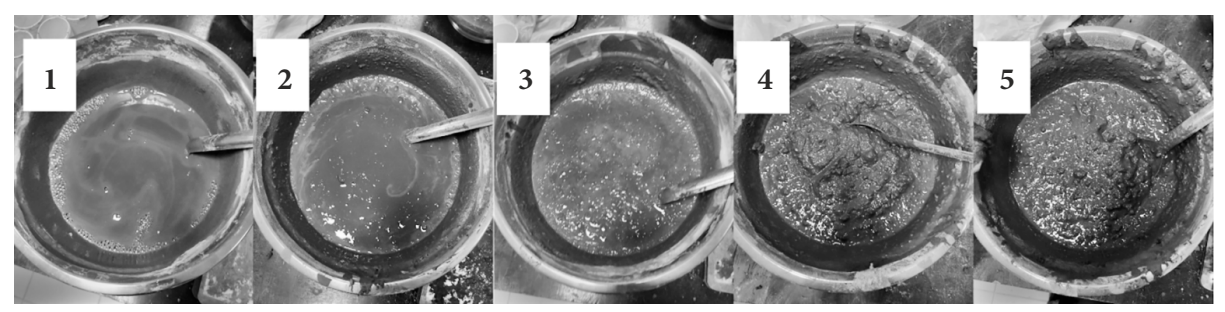

Figure 3. Cement and fly ash (C+FA) suspension: $1-100 \% \mathrm{C}+0 \%$; FA; $2-90 \% \mathrm{C}+10 \%$ FA; $3-80 \%$ C $+20 \%$ FA; $4-70 \%$ C + 30\% FA; $5-60 \%$ C + 40\% FA

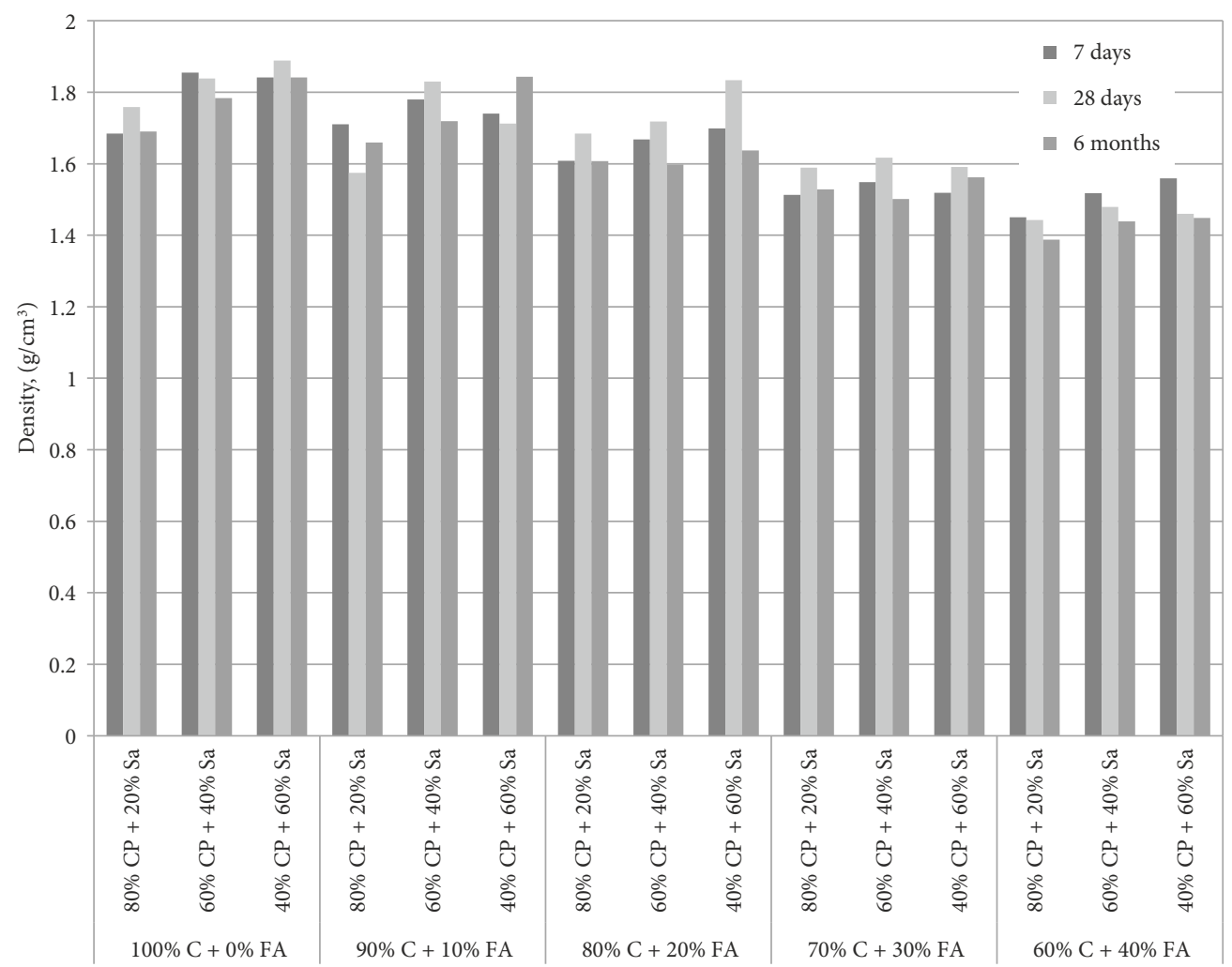

Figure 4. Density of investigated samples 
Suspension of cement and fly ashes $(\mathrm{C}+\mathrm{FA})$ was mixed with water in ratio 1:1, but when the quantity of FA was increased the suspension thickened and was not suitable to work (Figure 3), i. e. at $60 \% \mathrm{C}+40 \% \mathrm{FA}$ ratio was increased till 1:1.5. For different types of FA different water ratios are required in order to achieve maximum values of compressive strength (Fuller et al., 2018).

Samples after 24 hours were removed from forms and kept in a humid environment in exicators. After 7, 28 and 180 days density and compressive strength were determined to them.
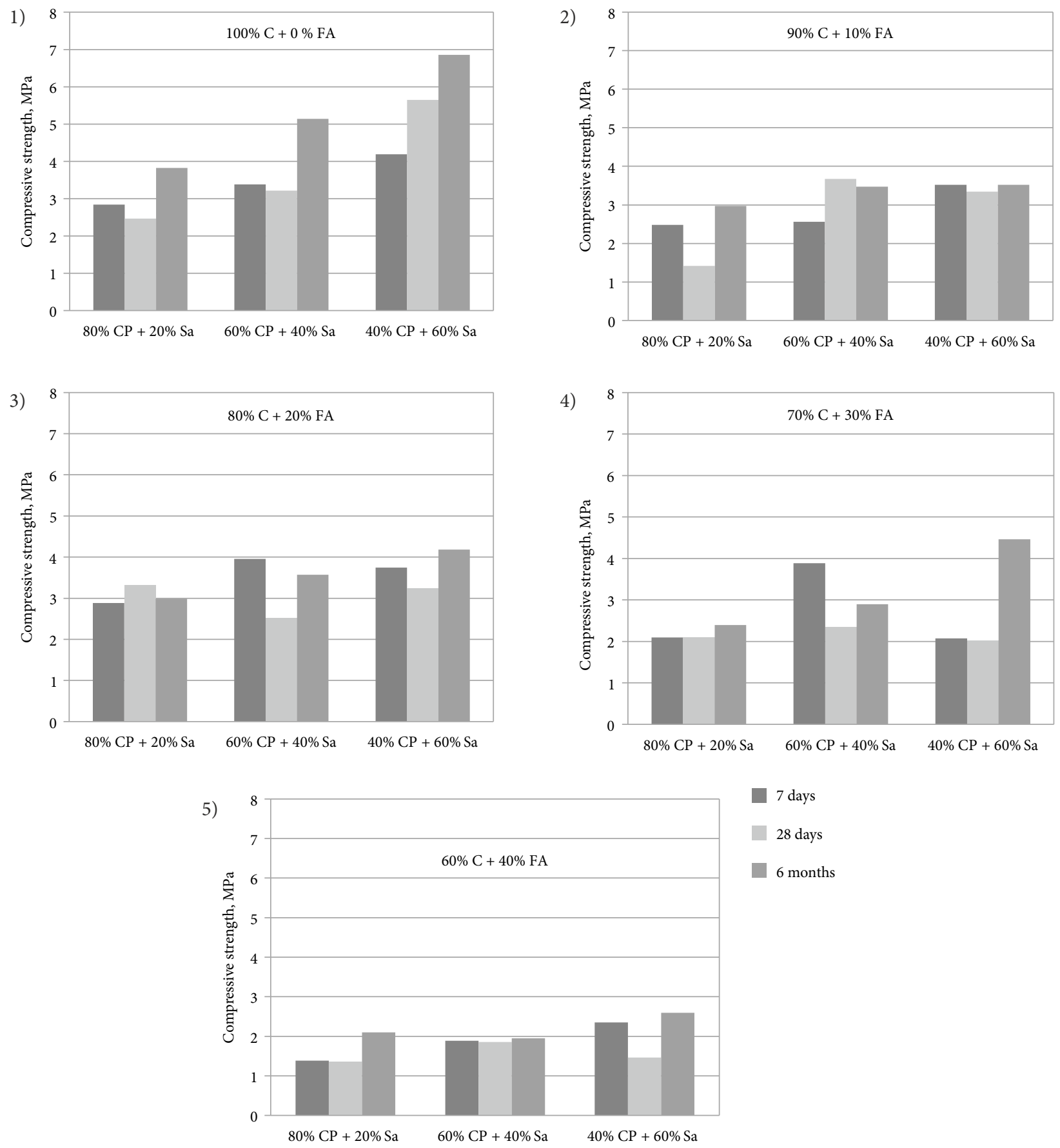
sity of samples was determined (Figure 4). It was obtained by measuring dimensions of samples and by weighing them. Density of samples of the same composition which were tested after different period of time, differs in average by $3.6 \%$, and the biggest distinction is $7.9 \%$. The minimum density equals to $1.388 \mathrm{~g} / \mathrm{cm}^{3}$, which was reached after 6 months for $60 \% \mathrm{C}+40 \% \mathrm{FA}$ and $80 \% \mathrm{CP}+20 \% \mathrm{Sa}$. The maximum density equals to $1.889 \mathrm{~g} / \mathrm{cm}^{3}$, which was

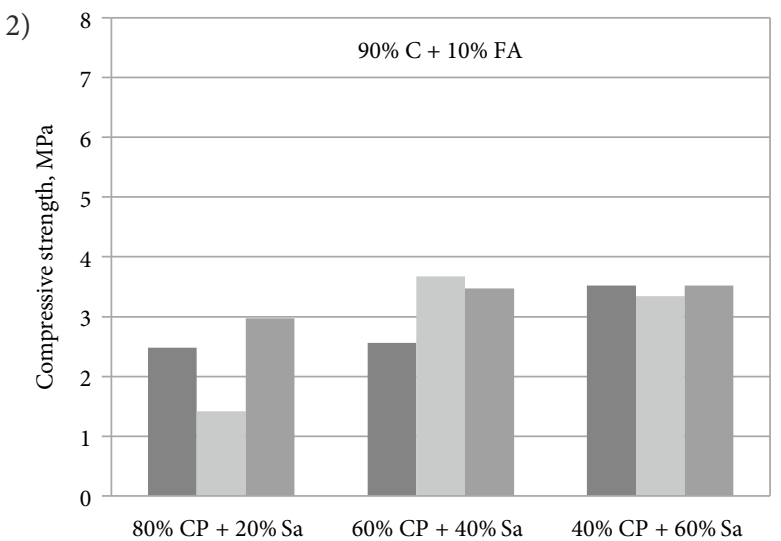

Figure 5. Compressive strength of samples: $1-100 \% \mathrm{C}+0 \% \mathrm{FA} ; 2-90 \% \mathrm{C}+10 \% \mathrm{FA}$; $3-80 \%$ C + 20\% FA; $4-70 \%$ C + 30\% FA; $5-60 \%$ C + 40\% FA 
reached after 28 days when there were $100 \%$ of cement and $40 \% \mathrm{CP}+60 \%$ Sa.

As standard results the data is used obtained from samples in which there is no FA. These results of uniaxial compression tests are the most clear and the most predicted (Figure 5). At 100\% C + 0\% FA and 40\% CP + 60\% Sa, values of strength increased evenly when evaluating the results during different periods of time. When $100 \% \mathrm{C}$ samples were mixed with $80 \% \mathrm{CP}+20 \% \mathrm{Sa}$ and $60 \mathrm{CP}+$ $40 \% \mathrm{Sa}$, strength values after 28 days in comparison with 7 days values weakened, and after 6 months strengthened. While increasing ratio of FA from 10 to $30 \%$, results of samples strength vary slightly and do not show big change of compressive strength.

Twelve of the fifteen mixtures had a lower strength after 28 days (in comparison with 7 days) (Figure 6). The greatest weakening was $43 \%$. Strength of mixtures comprised from $80 \% \mathrm{C}+20 \% \mathrm{FA}$ and $80 \% \mathrm{CP}+20 \% \mathrm{Sa} ; 100 \% \mathrm{C}$ and $40 \% \mathrm{CP}+60 \% \mathrm{Sa} ; 90 \% \mathrm{C}+10 \% \mathrm{FA}$ and $60 \% \mathrm{CP}+$ $40 \% \mathrm{Sa}$, after 28 days in comparison with 7 days increased (the greatest strengthening 43\%). After 6 months strength of thirteen of the fifteen mixtures increased, comparing to the strength after 28 days. The samples comprised of $90 \% \mathrm{C}+10 \% \mathrm{FA}$ ir $60 \% \mathrm{CP}+40 \% \mathrm{Sa} ; 80 \% \mathrm{C}+20 \% \mathrm{FA}$ ir $80 \% \mathrm{CP}+20 \%$ Sa weakened. After 28 days the samples strengthened comparing to the results after 7 days. Strength of thirteen of fifteen mixtures increased comparing to the strengths after 7 days (increasing up to 115\%). The results of samples were weaker, when the samples comprised of $70 \% \mathrm{C}+30 \% \mathrm{FA}$ and $60 \% \mathrm{CP}+40 \% \mathrm{Sa}$; $80 \% \mathrm{C}+20 \% \mathrm{FA}$ ir $60 \% \mathrm{CP}+40 \% \mathrm{Sa}$ (the greatest weakening 38\%).

The effect of sand and fly ash on samples density is shown in Figure 7 . The effect of sand on density, comparing $80 \% \mathrm{CP}+20 \% \mathrm{Sa}$ and $60 \% \mathrm{CP}+40 \% \mathrm{Sa}$, increased by $4.15 \%$. Comparing $80 \% \mathrm{CP}+20 \% \mathrm{Sa}$ and $40 \% \mathrm{CP}+$ $60 \% \mathrm{Sa}-$ density increased by $5.29 \%$. The effect of fly ash on density, comparing it with samples in which there is $100 \%$ cement and $10 \%$ FA is added constantly, decreases by $3.7 \% ; 6.9 \% ; 13.6 \%$ and $18.5 \%$.

Strength of samples, while comparing $80 \% \mathrm{CP}+20 \%$ Sa and $60 \% \mathrm{CP}+40 \% \mathrm{Sa}$, increased by $34.2 \%$, and comparing $80 \% \mathrm{CP}+20 \% \mathrm{Sa}$ and $40 \% \mathrm{CP}+60 \% \mathrm{Sa}-79.2 \%$ (Figure 7). Strength, when comparing with $100 \% \mathrm{C}$ and adding $10 \%$ FA each time, decreases by $34.4 \% ; 30.4 \%$; $38.6 \%$ and $56.4 \%$ (Figure 7 ). When ratio of FA with $\mathrm{C}$ is between $10-30 \%$, change of strength ranges in the interval of $5 \%$ and is not a tendency.

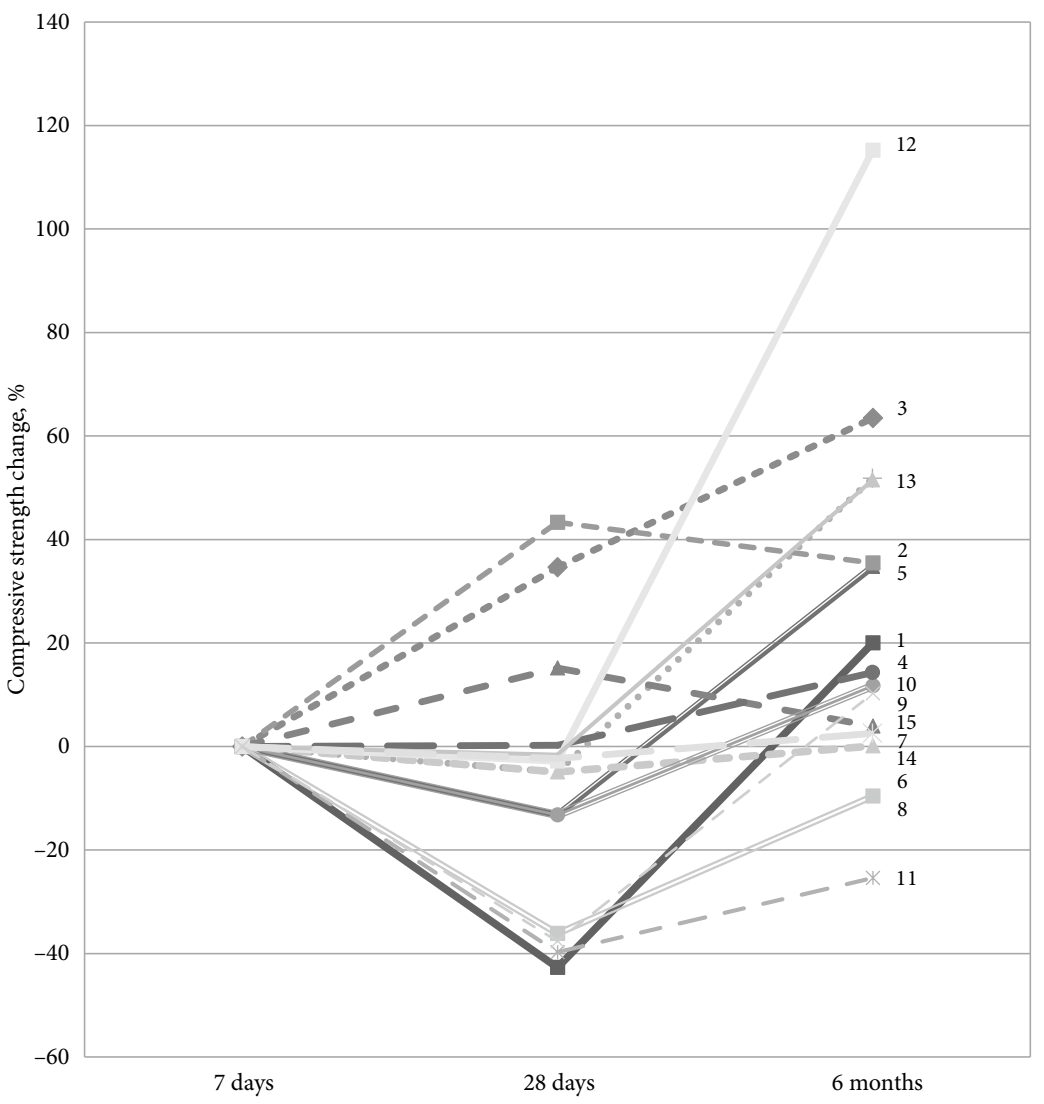

Figure 6. Relative change in strength after 28 days and 6 months in comparison with strength after 7 days: $-1-100 \% \mathrm{C}+0 \% \mathrm{FA}$ and $80 \% \mathrm{CP}+20 \% \mathrm{Sa} ; 2-100 \% \mathrm{C}+0 \% \mathrm{FA}$ and $60 \% \mathrm{CP}+40 \% \mathrm{Sa} ; 3-100 \% \mathrm{C}+0 \% \mathrm{FA}$ and $40 \% \mathrm{CP}+60 \% \mathrm{Sa} ; 4-90 \% \mathrm{C}+10 \% \mathrm{FA}$ and $80 \% \mathrm{CP}+20 \% \mathrm{Sa} ; 5-90 \% \mathrm{C}+10 \% \mathrm{FA}$ and $60 \% \mathrm{CP}+40 \% \mathrm{Sa} ; 6-90 \% \mathrm{C}+10 \% \mathrm{FA}$ and $40 \% \mathrm{CP}+60 \% \mathrm{Sa} ; 7-80 \% \mathrm{C}+20 \% \mathrm{FA}$ and $80 \% \mathrm{CP}+20 \% \mathrm{Sa} ; 8-80 \% \mathrm{C}+20 \% \mathrm{FA}$ and $60 \% \mathrm{CP}+40 \% \mathrm{Sa} ; 9-80 \% \mathrm{C}+20 \% \mathrm{FA}$ and $40 \% \mathrm{CP}+60 \% \mathrm{Sa} ; 10-70 \% \mathrm{C}+30 \%$ FA and $80 \% \mathrm{CP}+20 \% \mathrm{Sa} ; 11-70 \% \mathrm{C}+30 \% \mathrm{FA}$ and $60 \% \mathrm{CP}+40 \% \mathrm{Sa} ; 12-70 \% \mathrm{C}+30 \% \mathrm{FA}$ and $40 \% \mathrm{CP}+60 \% \mathrm{Sa} ; 13-60 \% \mathrm{C}+$ $40 \% \mathrm{FA}$ and $80 \% \mathrm{CP}+20 \% \mathrm{Sa} ; 14-60 \% \mathrm{C}+40 \% \mathrm{FA}$ and $60 \% \mathrm{CP}+40 \% \mathrm{Sa} ; 15-60 \% \mathrm{C}+40 \% \mathrm{FA}$ and $40 \% \mathrm{CP}+60 \% \mathrm{Sa}$ 

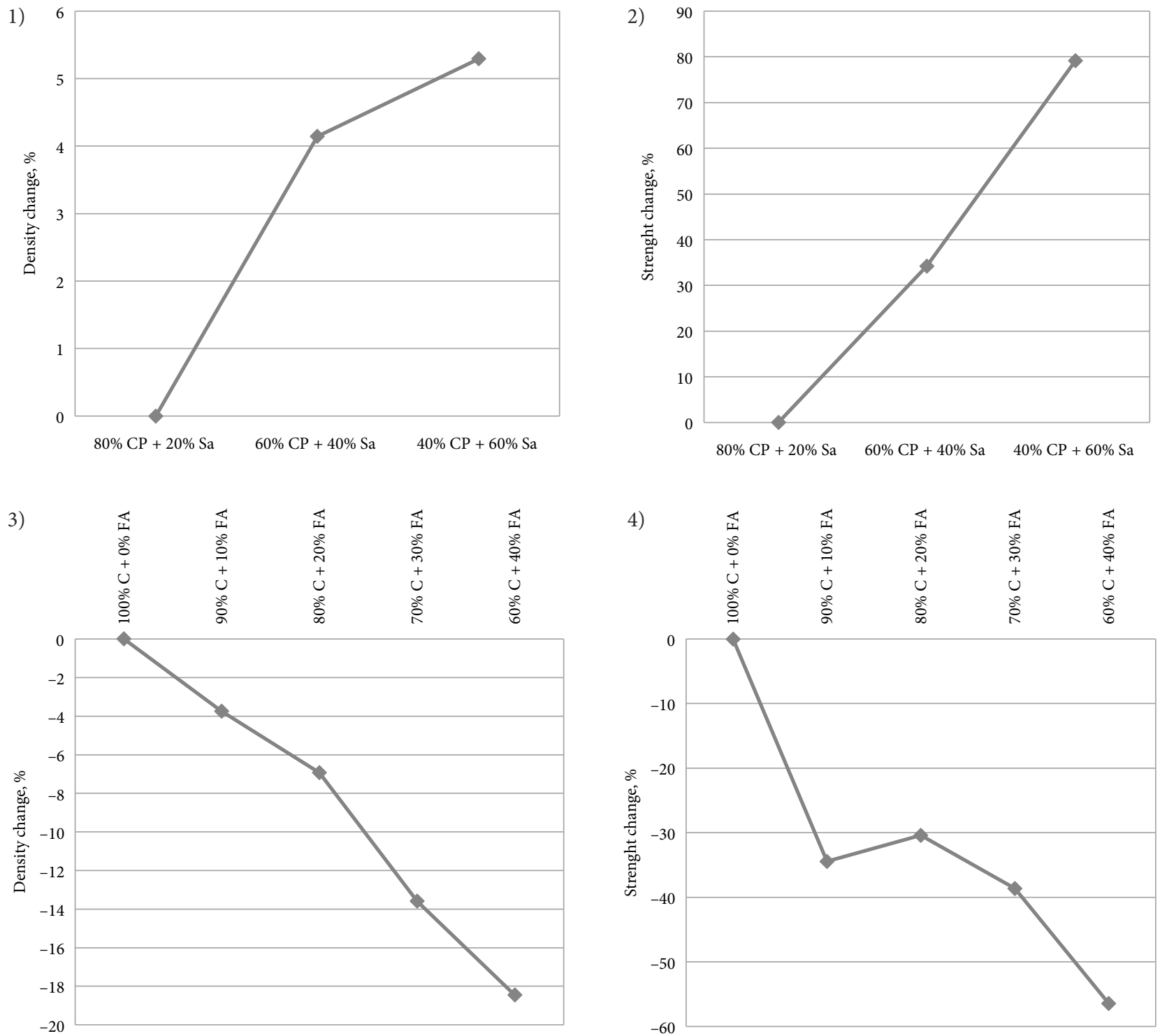

Figure 7. Effect of sand and fly ash on density and strength of samples after 6 months: 1 - Sa effect on density; 2 - Sa effect on strength; 3 - FA effect on density; 4 - FA effect on strength

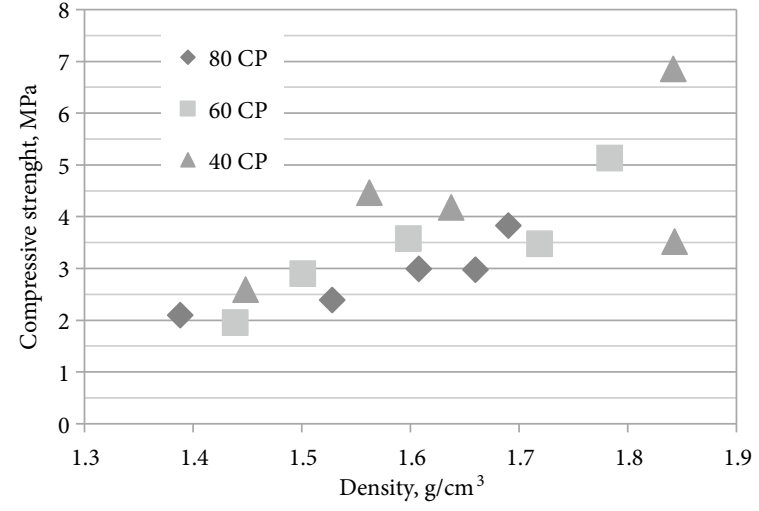

Figure 8. Density and compressive strength dependence on sand admixtures in clay

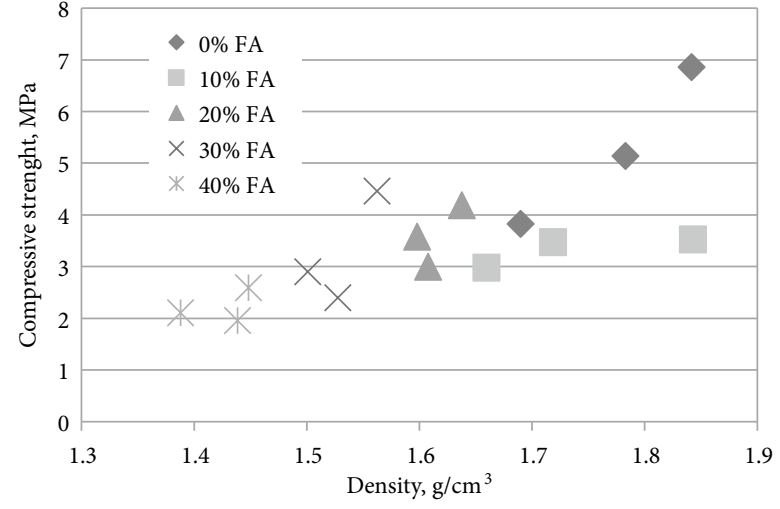

Figure 9. Density and compressive strength dependence on fly ash admixture in cement 


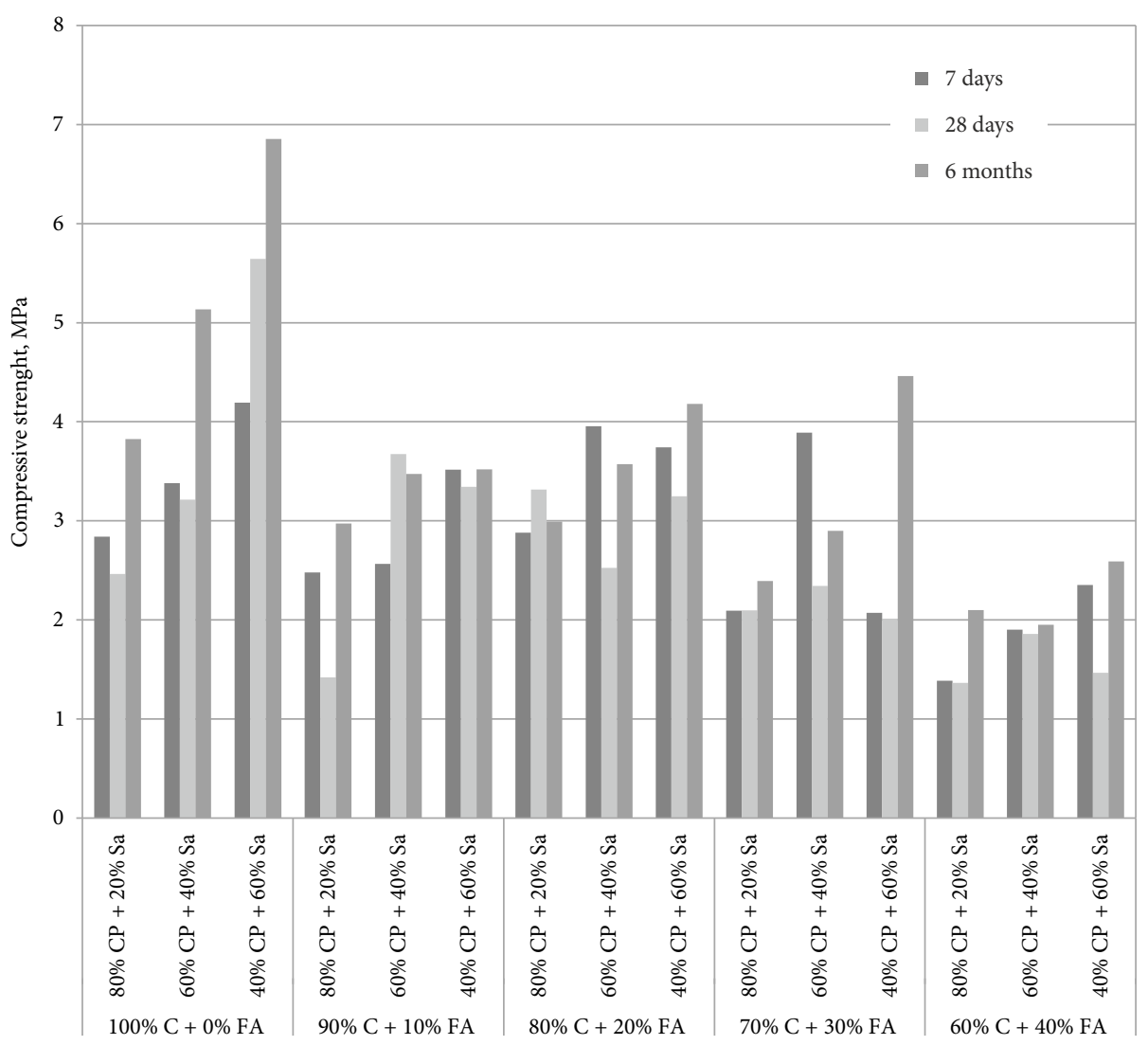

Figure 10. Compressive strength summary graph

Dependencies of density and compressive strength on sand and fly ashes are presented in Figures 8 and 9. By increasing quantity of sand in mixtures, density and strength of samples increases, and by increasing quantity of FA density decreases. When there is a $10-30 \%$ FA quantity, FA does not have effect on strength. The results of compressive strength of all tested samples are presented in Figure 10.

\section{Notations}

\section{Abbreviations}

C - Portland cement;

$\mathrm{CP}$ - Clay powder;

FA - Fly ash;

Sa - Sand;

W - Water;

$\mathrm{W}_{\mathrm{P}}$ - Plastic water content limit;

$\mathrm{W}_{\mathrm{L}}$ - Liquid water content limit.

\section{Conclusions}

After the tests and analysis of tests results such conclusions can be made:

1. Increasing FA quantity in cement and FA mixture, density and strength of samples decreases;

2. Quantity of sand admixtures in clay soil has a huge effect on compressive strength of samples;
3. In suspension of cement FA ratio increased from 10 to $30 \%$ does not have clear effect on strength. An obvious decrease in results of strength occurs when fly ash ratio in cement suspension reaches $40 \%$. According to the determined results it would be rational to limit fly ash quantity admixture in cement by $30 \%$ from mass of mixture;

4. After 28 days, while comparing with the results obtained after 7 days, compressive strength of samples decreased, and strengthening occured after 6 months. Temporary weakening of compressive strength everywhere was no less than 1.3 $\mathrm{MPa}$;

5. Even the minimal values of compressive strength after 6 months exceeded 1.7 $\mathrm{MPa}$. It is enough of such strength in geotechnics to conduct strengthening of soil and it is possible to argue that soil is strengthened.

\section{References}

Balkevičius, V., Christauskas, J., Gailius, A., Špokauskas, A., \& Siaurys, V. (2007). Analysis of some properties of model system from low-melting illite clay and fibrous mineral wool waste. Materials Science-Poland, 25(1), 209-217.

Česnauskas, V. (2018). Biomass fly ash additive for Portland cement and slag cement (Dissertation). Kaunas University of Technology. http://ktu.edu

Cristelo, N., Glendinning, S., Fernandes, L., \& Teixeira Pinto, A. (2011). Deep soft soil improvement by alkaline activation. 
Proceedings of the Institution of Civil Engineers Ground Improvement, 164(2), 73-82.

https://doi.org/10.1680/grim.900032

Cristelo, N., Soares, E., Rosa, I., Miranda, T., Oliveira, D. V., Silva, R. A., \& Chaves, A. (2013). Rheological properties of alkaline activated fly ash used in jet grouting applications. Construction and Building Materials, 48, 925-933. https://doi.org/10.1016/j.conbuildmat.2013.07.063

Essler, R., \& Yoshida, H. (2004). Jet grouting. In M. P. Moseley \& K. Kirsch (Eds.), Ground improvement (2nd ed., pp. 160-196). Taylor \& Francis.

https://doi.org/10.4324/9780203305201_chapter_5

European Commission. (2010). Being wise with waste: the EU's approach to waste management. Publications Office of the European Union.

Fuller, A., Stegmaier, M., Schulz, N., Menke, M., Schellhorn, H., Knödler, F., Maier, J., \& Scheffknecht, G. (2018). Use of wood dust fly ash from an industrial pulverized fuel facility for rendering. Construction and Building Materials, 189, 825-848. https://doi.org/10.1016/j.conbuildmat.2018.09.016

Giergiczny, Z. (2019). Fly ash and slag. Cement and Concrete Research. https://doi.org/10.1016/j.cemconres.2019.105826

Hemalatha, T., \& Ramaswamy, A. (2017). A review on fly ash characteristics - Towards promoting high volume utilization in developing sustainable concrete. Journal of Cleaner Production, $147,546-559$.

https://doi.org/10.1016/j.jclepro.2017.01.114

Lahtinen, P. (2001). Fly ash mixtures as flexible structural materials for low-volume roads (Finnra Reports 70/2001). Department of Civil and Environmental Engineering, Helsinki.

Lietuvos standartizacijos departamentas. (2013). Cementas. 1 dalis. Iprastiniu cementu sudetis, techniniai reikalavimai ir atitikties kriterijai (LST EN 197-1 2013).

Lietuvos standartizacijos departamentas. (2017). Geotechniniai tyrinejimai ir bandymai. Laboratoriniai grunto bandymai. 4 dalis. Granuliometrines sudeties nustatymas (LST CEN ISO/ TS 17892-4:2017).

Lietuvos standartizacijos departamentas. (2018). Geotechniniai tyrinejimai ir bandymai. Laboratoriniai grunto bandymai. 12 dalis. Takumo ir plastiškumo ribu nustatymas (LST CEN ISO/ TS 17892-12:2018).

Kolias, S., Kasselouri-Rigopoulou, V., \& Karahalios, A. (2004). Stabilisation of clayey soils with high calcium fly ash and cement. Cement and Concrete Composites, 27(2), 301-313. https://doi.org/10.1016/j.cemconcomp.2004.02.019

Marinković, S., \& Dragaš, J. (2018). Fly ash. In Waste and supplementary cementitious materials in concrete (pp. 325-360). https://doi.org/10.1016/B978-0-08-102156-9.00011-0

Mishra, N. K., \& Rath, S. (2011). Cost effectiveness of clayey soil \& moorum, treated with fly ash-lime for construction of low volume roads. International Journal of Civil and Structural Engineering, 2(1), 370-381.

Parsons, R. L., \& Kneebone, E. (2005). Field performance of fly ash stabilised subgrades. Ground Improvement, 9(1), 33-38. https://doi.org/10.1680/grim.2005.9.1.33

Pundinaitè-Barsteigienè, M., Bačinskas, D., Spudulis, E., \& Rumšys, D. (2017). MSWI bottom ash utilization in concrete mixes. Science - Future of Lithuania, 9(5), 524-530. https://doi.org/10.3846/mla.2017.1081

Rudžionis, Ž., \& Ivanauskas, E. (2004). Investigations into efective fly ash used in concrete. Journal of Civil Engineering and Management, 10(4), 303-309.

https://doi.org/10.1080/13923730.2004.9636323
Rutkauskas, A. (2018). Influence of mineral additives on the resistance of concrete to alkali-silica reaction (Dissertation). Vilnius Gediminas Technical University. http://dspace.vgtu.lt

Sližytė, D., Dagys, A., Medzvieckas, J., \& Milvydas, R. (2010, May 19-21). Using of jet grouting piles reinforced with central bars for low retaining walls. In Proceedings of The 10th International Conference "Modern Building Materials and Techniques” (pp. 1168-1173). Vilnius, Lithuania.

Stonys, R., Kuznetsov, D., Krasnikovs, A., Škamat, J., Baltakys, K., Antonovič, V., \& Černašejus, O. (2016). Reuse of ultrafine mineral wool production waste in the manufacture of refractory concrete. Journal of Environmental Management, 176, 149-156. https://doi.org/10.1016/j.jenvman.2016.03.045

Supancic, K., \& Obernberger, I. (2011). Wood ash utilisation as a stabiliser in road construction - first results of large-scale tests. Institute of Process and Particle Engineering. https://www.bios-bioenergy.at

Turner, J. P. (1997). Evaluation of western coal fly ashes for stabilization of low-volume roads. In M. Wasemiller \& K. Hoddinott (Eds.), Testing soil mixed with waste or recycled materials (pp. 157-171). ASTM International. https://doi.org/10.1520/STP15649S

Vaitkus, A., Grazulyte, J., Vorobjovas, V., Šernas, O. \& Kleiziene, R. (2017). Potential of MSWI bottom ash to be used as aggregate in road building materials. The Baltic Journal of Road and Bridge Engineering, 13(1), 77-86.

https://doi.org/10.3846/bjrbe.2018.401

Väntsi, O., \& Kärki, T. (2014). Mineral wool waste in Europe: a review of mineral wool waste quantity, quality, and current recycling methods. Journal of Material Cycles and Waste Management, 16, 62-72. https://doi.org/10.1007/s10163-013-0170-5

Zabihi-Samani, M., Mokhtari, S. P., \& Raji, F. (2018). Effects of fly ash on mechanical properties of concrete. Journal of Applied Engineering Sciences, 8(21), 35-40. https://doi.org/10.2478/jaes-2018-0016

Zokaitè, K. (2015). Geotechnical properties of triassic clay-cement mix. (Master's Thesis). Vilnius University. https://epublications.vu.lt 